\title{
VIDEO ADS' CREATIVITY AND STRUCTURE INFLUENCE ON BRAND CONGRUENCE AND ENGAGEMENT
}

\author{
Sónia de Almeida Ferreira ${ }^{1}$, Sara Santos ${ }^{2}$ and Pedro Espírito Santo ${ }^{3}$ \\ ${ }^{I}$ Center for Studies in Education and Innovation, School of Education, Polytechnic of Viseu, Portugal \\ ${ }^{2}$ School of Education, Polytechnic of Viseu, Portugal \\ ${ }^{3}$ School of Technology and Management of Oliveira do Hospital, Polytechnic of Coimbra, Portugal
}

\begin{abstract}
Social networks play an important role in the life of today's societies and consumers are engaging more online with brands. Brands create and share information and special video ads on social networks, and, in the context of the COVID-19 pandemic, social networks allow brands to communicate with their consumers simply and quickly. Therefore, creativity and narrative structures are important for consumers. Brands are producing video ads that show consumers' day context in order to obtain greater social media engagement. Considering that, this paper aims to study whether that goal is being achieved. The empirical research, from which we obtained 427 responses and which was tested using structural equations using the AMOS software, allows to conclude that creativity, the structure of the narrative and the consumer's congruence with the brand are determinants of engagement in social media. Further, presents practical and theoretical recommendations.
\end{abstract}

\section{KEYWORDS}

Video Ads; Narrative Structure; Creativity; Brand Congruence; Social Media Engagement

\section{INTRODUCTION}

The human capacity to create narratives as a way of communicating is one of the oldest tools we know. Disciplines such as marketing and advertising easily recognize the power of storytelling and the importance of implementing approaches that provoke individuals' attitudes and behavior. And this is a reality never achieved before and that affects consumers of the most varied generations, classes and profiles. 
IADIS International Journal on WWW/Internet

In fact, new technologies have enabled this and have allowed barriers to be broken, not only temporal but also spatial. The individual is now in continuous contact with information and content, globally. As a consumer you can search and see what you want, where you want and when you want. Furthermore, with the new media, brands have access to new ways to disseminate information and enhance collaboration, community, conversation and sharing between consumers and among them and brands (Hennig-Thurau et al., 2010). Thus, social media platforms have been adopted in a large part of marketing strategies to enhance consumer engagement (Harrigan, Evers, Miles, \& Daly, 2017) through stories (Brechman \& Purvis 2015).

We agree that the receptivity to advertising messages differs from individual to individual, considering their contexts and demographic, social, educational characteristics, among others, but, according to Brechman and Purvis (2015), they are increasingly willing to be transported to the advertising narrative, which further enhances this area of expertise.

On the other side, as consumers prefer products congruent with their self-concept, self-congruence could trigger emotional, attitudinal and behavioral reactions to the brand (Grohmann, 2009). So, engage consumers special through social media platforms is essential to create an effective strategic role in branding and advertising.

Considering the framework, this study aims to analyze whether the advertising videos produced by the brands that show, more and more, the daily lives of the public are being effective in engaging in social media. Specifically, this study analyses the effects of creativity and the structure of narratives on social media engagement. Additionally, we studied the mediating effects of brand congruence. A questionnaire survey was applied and the data obtained were tested using structural equations in the AMOS software.

\section{LITERATURE REVIEW}

\subsection{Video Ad's Narrative Structure and Creativity}

It is important to clarify the concept of transportation for the advertising narrative, initially proposed by Green, in 1996. According to the author, it defines the process of transporting the individual to a fictional reality created from a narrative, creating evident effects on their beliefs, attitudes and behaviors (Green \& Clark, 2012), losing access to the real and experiencing the emotions evoked by history (Green \& Block, 2000).

In terms of the structure narrative creation, Escadas (2007) states that the ads are not openly persuasive. They present an affective component that unconsciously directs the consumer. Structurally, the narratives are based on a plot with incidents and surprises, on characters to whom conflicts and events happen and at a climax moment where the resolution of the story is presented (Snowden, 1999; van Laer et al., 2014) and the major conflict finally resolved.

According to Bruner (Brechman \& Purvis, 2015), the traditional definitions propose that the narratives present a chronology, organizing the events with a temporal dimension, finding a beginning, middle and end. In addition, they seek to achieve causality, that is, the structuring of the elements of history in an organized manner that allows for causal inference. In addition to including emotional appeals, narratives are endowed with structural elements that "provide context, usually establishing an environment that has physical, social and temporal components, and the story is further enhanced with the use of images to guide consumers' imaginations, involvement or immersion in the story (Brechman \& Purvis, 2015). 
Audiovisual advertising also has specific elements of production, the so-called packshots. It is the plans of dramatic action that have the function of objectifying the product or service commercially. According to Camilo (2005), without the packshot there is no audiovisual advertising narrative. It is essential for the distinction between the advertised product / service and the other elements of the narrative. Usually the packshot appears at the end of the advertising video and is accompanied by subtitles and / or voiceover.

Along with information and entertainment, creativity is also understood as a constructor of consumer attitudes and associations towards ads (Gao \& Koufaris, 2006; Taylor, Lewin, $\&$ Strutton, 2011).

According to Lee and Hong (2016), both informativeness and creativity, often emphasized in public literature, prove to be the main drivers of behavior favorable to advertisements on social networking services, promoting purchase intentions.

In addition, according to Dessart (2018), the commercial strategy must also involve balancing the elements of the narrative with facts. Using facts, figures and arguments only tends to alienate the individual and promote a distant attitude (Gottschal, 2012), but the symbiosis between the structure of the narrative and the elements of the story creates a powerful tool for transmitting information (Brechman \& Purvis 2015) and, when created efficiently, allows for more favorable cognitive responses, warm feelings and positive attitudes of the narrative advertisement, when compared to the advertising of arguments (Chang, 2009). Thus, we tested the following hypothesis:

H1: Creativity has a positive impact on narrative structure.

\subsection{Brand Congruence}

Consumers use brands that give meaning to their self-concept to themselves and to others (Aaker, 1999). The brand congruence theory evidences that people are satisfied with brands or products that are congruent with their actual or desired self-concept (Sirgy \& Su, 2000). So, brands represent social or cultural meaning congruent with consumer's own self-concept (Sirgy, 1982).

For Malär et al (2011) self-concept include a cognitive and affective perspective because first costumers perceive their self and then the similarity with brand personality, which results in brand congruity perceived by costumers.

Sirgy (1982) evidences that self-image congruity is a process whereby consumers purchase products/brands congruent with symbolic attributes similar to their images of themselves. This congruence has impacts on purchase behaviour, because consumers use products according with their self-image (Pedersen, Nysveen, \& Thorbjørnsen, 2003).

The consumer's mental representation of the self-concept consists in two essential aspects (e.g. Sirgy, 1982): the 'actual self' (one's self-image as it currently is) and the 'ideal self' (the image of oneself as one would like to be) that are linked to relevant motives that impact brand congruence: self-consistency and self-esteem (Sirgy, 1982).

Consumers use brands that match with the group's image which them want to belong (Klipfel, Barclay, \& Bockorny, 2014) and social networking sites affects ideal social self-image and consumer's socialization (White \& Dahl, 2007).

Studies by Mahjoub et al. (2015) demonstrated that actual self-congruence affects brand attachment and involvement. When customers use brands similar to their self, they build positive feelings, connection and loyalty to the brand (Mahjoub et al., 2015). So, Consumption behavior would be affected by individuals' self and social image (Alnawas \& Altarifi, 2015). 
IADIS International Journal on WWW/Internet

Companies seek similarity between customers actual self and brand personality, which is named self-congruence. (Mälar et al., 2011). Nowadays, companies try to create emotional connection with consumers with brand congruence with consumers' actual self or consumers' ideal self (Mälar et al., 2011).

Because "the consumer tends to purchase brands which have a similar image to his/her self-image" (Engel, 2001, p. 399). Some authors argue that self-brand congruence match with consumers self on dimensions on cultural values (Torelli et al., 2012), gender identity (Grohmann, 2009) and brand personality (Mulyanegara et al., 2007). Addictionally, narrative ads, and their creativity have an important role positive attitudes as a brand congruence (Gottschal, 2012). Therefore, we proposed the following hypotheses:

$\mathrm{H} 2$ : Creativity has positive effects on brand congruence

H3: Narrative Ads Structure has positive effects on brand congruence

\subsection{Social Media Engagement}

Consumer engagement has been defined in a number of ways in the literary, from emotional attachment to a brand (Calvert et al., 2014), to more cognitive, behavioral or emotional perspectives (Gambetti \& Graffigna, 2010). Hollebeek et al. (2014) define consumer brand engagement in social media as the ability to create a psychological state in the consumer's mind as they interact with the brand. On the other side, the concept of "social media" refers to "tools for social interaction, using highly accessible and scalable communication techniques - such as web-based, mobile technologies - to turn communication into interactive dialogue" (Coulson, 2013, p. 1).

People use different social media platforms to satisfy different needs (Phua, Jin, and Kim, 2017) and interact according with these needs. Muntinga, Moorman and Smit (2011) identified six motivations for use social media: entertainment, integration and social interaction, personal identity, information (from studies of McQuail, 1983) and added remuneration and empowerment. Hennig-Thurau et al. (2004) demonstrated that consumers' needs for integration and social interaction are the main motivators for internet use. While Dolan, Seo, and Kemper (2019) emphasized relational and entertaining content as the most emotional appeals used in social media.

Several studies measure engagement in social media in a specific period of time through likes, shares, and comments (for example in Facebook and Instagram) (De Vries, Gensler, \& Leeflang, 2017). This interaction in social media varies according to different levels of engagement from "following" (lower level) to "commenting" (higher level) (Pentina et al., 2018).

Muntinga et al. (2011) proposed a model of consumers' online brand-related activities (COBRAs) that distinguishes three levels of engagement: consumption, contribution and creation. Based in this model, Tsai and Men (2013) based on consumers' brand related activities on online media (COBRA's) model of Muntinga, Moorman, and Smit's (2011) evidence two levels of engagement: passive consumption (e.g., viewing videos and pictures, reading product reviews) and active content contributing (e.g., responding to comments and other SNS posts, posting one's own product reviews, uploading user-created videos and pictures).

Facebook is the social network site with more users around the world, and it is the platform with frequent use to form and maintain social interactions and relationships (Dunbar, 2016). When the Facebook involvement is higher, users are perceived as more "likable", being sociable 
and fun (Utz, Muscanell and Khalid, 2015). For this, it is an important tool to achieve customer engagement (Li et al., 2020).

With social media, people are more connect and engaged, sharing content and information (Aslam et al., 2018). As a result, engagement in social media allows creating relationships between brands and multiple actors, engaging consumers (Westberg, Stavros, Smith, Munro, \& Argus, 2018), playing a strategic role in branding (Hajli, Shanmugam, Papagiannidis, Zahay, $\&$ Richard, 2017). As consequence it also increases loyalty (Schivinski and Dabrowski, 2015), brand awareness/associations, perceived quality (Schivinski and Dabrowski, 2015) as well as purchases (Brodie et al., 2013) and firm competitiveness (Mishra, 2019).

On the other side, online communities can also build and maintain trust relationships, improving communication and brand-costumer interactions (Palmatier, Dant, Grewal and Evans, 2006) and increasing also subjective wellbeing (Verduyn et al., 2017).

For researches strategically use of social media "should take deliberate initiatives to motivate and empower customers to maximize their engagement value and yield superior marketing results" (Li et al., 2020, p. 4).

Creative video ads increase motivation to process the ad and improve the attitude toward the ad (Lee \& Hong, 2016). Therefore, we proposed the following hypotheses:

$\mathrm{H} 4$ : Creativity video ads is positive related with social media engagement.

H5: Narrative Ads Structure has positive effects on social media engagement.

Positive brand attitudes/evaluations (Graeff, 1997) and social media engagement appears as a consequence of self-brand congruence, because consumers express brand preference, loyalty and emotional attachment (Malär et al., 2011). Thus, we proposed the following hypothesis:

H6: Self Brand congruence is positively related with social media engagement.

\section{METHODOLOGY}

The research was conducted in a telecommunications industry. Telecommunications industry is a competitive industry, with low differentiation level of products and services, where advertising and creativity play an important role in competitiveness. In this environment, brands are changing their advertising to engage more and more customers. In context of COVID-19 pandemic environment, we analysed a Vodafone advertising video produced when people are in confinement (https://www.youtube.com/watch? $\mathrm{v}=$ Geus4SNwVkQ), whose message was "Let's stay home. Let's stay connected".

To test the proposed hypothesis, at first stage, a video ad was presented and, at a second stage, an online survey to collect data from telecommunications customers was conducted. All the measures were adapted from prior studies and have been confirmed to be reliable and valid. Before the questionnaires were distributed, all questions were translated into Portuguese by a specialized technician. Some items were slightly modified to fit telecommunications' advertising context.

\section{Measures}

In order to measure various constructs of the research model, the questionnaire uses a five point Likert scale, ranging from " 1 " to " 5 " (1=strongly disagree, $5=$ strongly agree). Specifically, creativity was measured using the items adapted from Lee and Hong (2016), narrative advertising structure was measured following Dessart (2018), brand congruence was measured 
IADIS International Journal on WWW/Internet

by the items from Hinsch, Felix, and Rauschnabel (2020) and we measured engagement from Schivinski, Christodoulides, and Dabrowski (2016).

Data collection Procedure and sample

After translation, the questionnaire was pre-tested by a sample of 15 respondents. Based on your comments and suggestions, the formats and essays have been revised to ensure reliability and clarity. Information about the proposes of the study have been provided at the beginning of the questionnaire. The data were collected through a self-completion survey. The sample has 427 valid responses and the data collection took place from April to June 2020. The demographic profiles were reported in table 1.

Table 1. Demographic profiles $(\mathrm{N}=427)$

\begin{tabular}{cccc}
\hline Variable & Category & Frequency & Valid \% \\
\hline Gender & Male & 123 & 28.8 \\
& Female & 304 & 71.2 \\
\hline Age & < 20 years & 43 & 10.1 \\
& 20 to 29 years & 219 & 51.3 \\
& 30 to 39 years & 55 & 12.9 \\
& 40 to 49 years & 60 & 14.1 \\
& 50 to 59 years & 43 & 10.1 \\
& up to 60 years & 7 & 1.6 \\
\hline
\end{tabular}

Table 1 shows that $71,2 \%$ are female and most of the observations are originate from individuals below 40 years of age $(\mathrm{N}=274 ; 74,3 \%)$ (Table 1$)$. The respondents are age average equal to 30.03 years old $(\mathrm{SD}=12.33)$.

\section{RESULTS}

The sample size of this study permits the usage of multivariate analysis techniques like Structural equation modelling (SEM) through maximum likelihood estimation, considering the rule of 5:1 (responses:items) (Hair, Black, Babin, \& Anderson, 2018). SEM is a multivariate analysis technique deployed to examine the proposed relationships. This technique that takes into account the measurement error in the model and it is recommended for theory testing in case of large datasets above 200 samples.

We used AMOS v.26 software and the research through SEM was analysed in two stages. First, the we analysed the measurement model (reliability and validity) and second, we analysed the relationship between constructs and evaluate the model fit.

\section{Preliminary data analysis}

At first step, common method bias was analysed, because data were collected from the same source and there have been a problem with commom method bias. To attend to this potential bias, ex-ante and ex-post procedures was employed. Ex-ante procedures were followed by Podsakoff, MacKenzie, Lee, and Podsakoff (2003) recommendations. We pre-test the survey to avoid vague concepts and complex syntax and double barrelled questions. At the first page of the survey respondents were informed that answers are anonymous and there are no right or 
wrong answers to each question. Ex post, Harman's one factor test was executed and the result showed four factors and fist factor explained $32.15 \%$ of the variance.

A preliminary data analysis was conducted and we ran a series of regression models on the various constructs to calculate the Variance Inflactor Factor (VIF). The VIF value is below the threshold (VIF <5) and therefore we assume that multicollinearity is not considered problematic. We also verified the Skewness (Sk) and Kurtosis ( $\mathrm{Ku})$ and we concluded that the items do not diverge from normality ( $\mathrm{Sk}<3$; $\mathrm{Ku}<7$ ) (Hair et al., 2018). Additionally, we calculated the Kaiser-Meyer-Olkin (KMO) as well as Bartlett's test of sphericity to measure sampling adequacy. The KMO is $0.835(\mathrm{KMO}>0.7)$ and Bartlett's test is significant at $\mathrm{p}<0.05$. Therefore, the data are suitable for factor analysis.

\section{Measurement model}

The first step of the SEM analysis is the measurement analysis. We carried out the measurement model through confirmatory factor analysis (CFA) to assess reliability and validity. The results of model fit indices were acceptable $\left(\chi^{2}=261.884 ; d f=97\right.$; GFI $=0.929$; $\mathrm{CFI}=0.969 ; \mathrm{NFI}=0.951 ; \mathrm{IFI}=0.969 ; \mathrm{TLI}=0.961 ; \mathrm{RMSEA}=0.080)$.

Table 2. Results of the measurement model

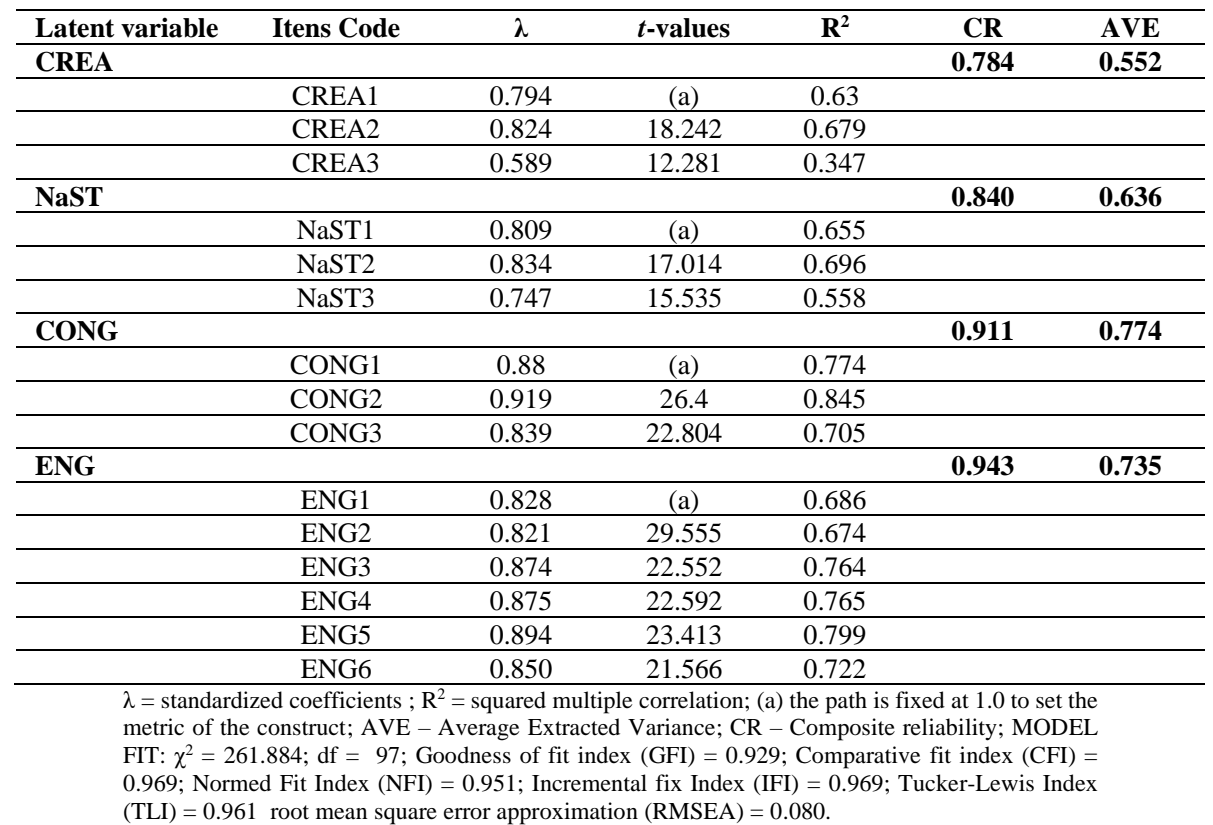

Convergent validity and reliability was examined through the Average Variance extracted (AVE) and Composite Reliability (CR) (Bagozzi \& Yi, 1988; Fornell \& Larcker, 1981). Thus, table 2 shows that AVE (ranging from 0.552 to 0.774) and CR (ranging from 0.784 to 0.943 ) are above the threshold values (AVE $>0.5 ; \mathrm{CR}>0.7$ ). Additionally, we examine that standardized loadings $(\lambda)$ are above the recommended value for each construct $(\lambda>0.7)$ and their significance is considered $(\mathrm{p}<0.05)($ Chin, 1998). 


\section{Discriminant validity}

Moreover, discriminant validity was examined. Table 3 present a Fornell and Larcker criterion (Fornell \& Larcker, 1981) to examine discriminant validity and we confirmed that all AVE values are higher than squared inter-construct correlation estimates.

Table 3. Discriminating Validity - criterion of Fornell and Larcker (1981)

\begin{tabular}{lllll}
\hline Construct & CREA & NaST & CONG & ENG \\
\hline CREA & 0.552 & & & \\
NaST & 0.334 & 0.636 & & \\
CONG & 0.437 & 0.334 & 0.774 & \\
ENG & 0.387 & 0.097 & 0.336 & 0.735 \\
\hline \multicolumn{5}{c}{ Diagonal entries are AVE values; ${ }^{*}$ all correlations are significant at } \\
level 1\% \\
CREA=Creativity; NaST=Narrative Advertising Structure; \\
CONG=Brand Congruence; ENG=Social Networks Engagement;
\end{tabular}

The results indicate that constructs are unidimensional and show acceptable levels of reliability, convergent validity and discriminant validity.

\section{Structural Model}

The second step of the SEM analysis is the hypothesis testing through examination of the structural model and the results are shown in table 4 . The result of the chi square $\left(\chi^{2}\right)$ test is 365.007 with $d f=98$, which is statistically significant $(\mathrm{p}<0.01)$. Moreover, the global fit indices recommend that the model has an acceptable fit $(\mathrm{GFI}=0.901$; $\mathrm{CFI}=0.901$; NFI $=0.932$; $\mathrm{IFI}=0.949$; TLI=0.938; RMSEA=0.080). The structural paths support hypotheses H1, H2, h3, $\mathrm{H} 4, \mathrm{H} 5$ and $\mathrm{H} 6$.

Table 4. Hypothesis Testing - Direct, Indirect and Total Effects

\begin{tabular}{ccccccc}
\hline Hip & Path & $\boldsymbol{\beta}$ & Std Error & t-value & p-value & result \\
\hline H1 & CREA $\rightarrow$ NaSt & 0.577 & 0.045 & 10.16 & $p<0.001$ & Supported \\
H2 & CREA $\rightarrow$ CONG & 0.491 & 0.063 & 8.42 & $p<0.001$ & Supported \\
H3 & NaSt $\rightarrow$ CONG & 0.294 & 0.076 & 5,194 & $p<0.001$ & Supported \\
H4 & CREA $\rightarrow$ ENG & 0.479 & 0.081 & 7.116 & $p<0.001$ & Supported \\
\hline H5 & NaSt $\rightarrow$ ENG & -0.184 & 0.089 & -3.1 & $p<0.01$ & Not Supported \\
H6 & CONG $\rightarrow$ ENG & 0.376 & 0.071 & 5.935 & $p<0.001$ & Supported \\
Notes: $\beta=$ Standardized Path Coefficients; $\mathrm{R}^{2}$ : NaST $=0.333 ;$ CONG; 0.495 ; ENG $=0.461$ & \\
CREA=Creativity; NaST $=$ Narrative Advertising Structure; CONG=Brand Congruence; ENG=Social Networks Engagement. \\
Model Global Fit: $\chi^{2}=365.007 ; d f=$ 98; Goodness of fit index (GFI) =0.901; Comparative fit index (CFI) =0.900; Normed \\
Fit Index (NFI) = 0.932; Incremental fix Index (IFI) = 0.949; Tucker-Lewis Index (TLI) = 0.938; Root Mean Square Error \\
Approximation (RMSEA) = 0.080.
\end{tabular}

\section{DISCUSSION}

The results evidenced the explanation of the engagement in social networks by the variables included in the model $\left(\mathrm{R}^{2}=0.461\right)$. The internet in general and social media networks specifically, generate content for users and the amount of information that they receive today is vast. This empirical study examined the creativity impacts on narrative structure. $\mathrm{H} 1$ is confirmed by our study ( $\left.\beta_{\text {CREA } \rightarrow \text { NaSt }}=0.577 ; p<0.001\right)$ as Chang (2009) states. The novelty and 
surprising elements in online video ads provide a greater understanding of the structure of the video (Brechman \& Purvis 2015).

In order to test $\mathrm{H} 2\left(\beta_{\mathrm{CREA}} \rightarrow \mathrm{CONG}=0.491 ; p<0.001\right)$ and $\mathrm{H} 3\left(\beta_{\mathrm{NaST}} \rightarrow \mathrm{CONG}=0.294 ; p<0.001\right)$, our investigation support that narrative ads, and their creativity has some effects on brand congruence. Consumers use brands that are congruent with themselves and their self-concept and for Malär et al (2011) the self-concept includes a cognitive and affective perspective. Our study, which presents creative elements and a narrative structure, corroborates the study by Gottschal (2012). Therefore, the creativity and the narrative structure of the propagating ad positively influence congruence as a positive attitude to the brand.

To support the hypothesis $\mathrm{H} 4$ ( $\beta$ CREA $\rightarrow \mathrm{ENG}=0.479 ; p<0.001$ ), we analyse that creativity motivates the attitude toward social media engagement like Lee and Hong (2016) because, when video ads are efficiently created they allows more favorable cognitive responses (Chang, 2009).

Our empirical study did not support the positive relationship stated between Narrative Ads Structure and social media engagement. The hypothesis H5 is not confirmed. We found some explanations for this. It is possible that the age of the respondents does not allow us to conclude about this relationship. In addition, our study has a sample with a strong percentage of women. Additionally, the character of the video may be unknown to individuals and therefore, there is no connection between the video advertisement and the intention to engage in social media networks.

Finally, we state that $\mathrm{H} 6\left(\beta_{\mathrm{CONG}} \rightarrow \mathrm{ENG}=0.376 ; p<0.001\right)$ is supported. This result is related with the conclusions of Malär et al. (2011). Thus, positive brand evaluations and social media engagement appears as a consequence of self-brand congruence.

\section{CONCLUSION}

Due to the centrality of social networks today, the empirical study presented here contributed to the advance of theoretical knowledge and has practical implications for management.

The study presents a model in which most of the causal relationships between the constructs were supported by our analysis. The model presented has a good fit.

This research concludes that there is a positive relationship between creativity and narrative ad structure and that the structure of video ads is better interpreted if creativity is present. In this way, brands must reinvent themselves to create amazing videos for their consumers.

Our study also demonstrates that brand congruence is influenced by creativity and through narrative structure. Therefore, video ads that meet each consumer's self-concept are ads that fit to consumer's values. Thus, brands with video ads perceived by consumers as similar to themselves will have more proximity to consumers and also a greater congruence.

In addition, the engagement of social media is explained by the congruence with the video ad, because when brands are congruent with individuals, they develop responses to the brand.

Firms should reflect on these results and promote their creativity on video ads to create mental representations on consumers' minds and, therefore, get more and mode engagement from their consumers.

Despite the important results, we considered that future researches could include other variables to help explain the model.

Thus, as further research, we suggest a model with the experience with the brand as a moderating variable. 
IADIS International Journal on WWW/Internet

In addition, our study only considered a sample of residents in Portugal. The analysis of users, from other countries, may be relevant for the explanation of the model presented.

\section{ACKNOWLEDGEMENT}

This work is funded by National Funds through the FCT - Foundation for Science and Technology, I.P., within the scope of the project Ref ${ }^{a}$ UIDB/05507/2020. Furthermore, we would like to thank the Centre for Studies in Education and Innovation (CI\&DEI) and the Polytechnic of Viseu for their support.

\section{REFERENCES}

Aaker, J. L. 1999. The malleable self: The role of self-expression in persuasion. Journal of Marketing Research, Vol. 36, No. 1, pp. 45-57.

Alnawas, I. and Altarifi, S. 2015. Exploring the role of brand identification and brand love in generating higher levels of brand loyalty. Journal of Vacation Marketing, Vol. 22, No.2, pp. 111-128.

Aslam, U. et al, 2018. Exploring the sources and role of knowledge sharing to overcome the challenges of organizational change implementation. International Journal of Organizational Analysis, Vol. 26, No. 3, pp. 567-581.

Bagozzi, R. P., \& Yi, Y. 1988. On the evaluation of structural equation models. Journal of the Academy of Marketing Science, 16(1), 74-94. doi: 10.1007/BF02723327

Brechman, J. M. and Purvis, S. C., 2015. Narrative, transportation and advertising. International Journal of Advertising, Vol. 34, No 2, pp 366-381.

Brodie, R.J. et al, 2013. Consumer engagement in a virtual brand community: an exploratory analysis. Journal of Business Research, Vol. 66, No. 1, pp. 105-114.

Calvert et al., 2014. Using Implicit Methods to Develop an Objective Measure of Media Brand Engagement. International Journal of Market Research, Vol. 56, No. 1, pp. 15-32.

Camilo, E. 2004. Duração mínima, alusão máxima ou a ditadura da elipse. Apontamentos sobre a montagem do filme de publicidade. Proceedings of Congresso de Ciências da Comunicação, pp.

Chang, C. 2009. Being Hooked by editorial content: The implications for processing narrative advertising. Journal of Advertising. Vol. 38, No 1, pp 21-34.

Chin, W. 1998. The Partial Least Squares Approach to Structural Equation Modeling. Modern Methods for Business Research, 8.

Coulson, D. C. 2013. Dynamics of social media, politics in the Arab World. Global Media Journal Spring, Vol.12, pp.1-20.

Dessart, L. 2018. Do ads that tell a story always perform better? The role of character identification and character type in storytelling ads. International Journal of Research in Marketing. Vol. 35, No 2, pp. 289-304.

De Vries, L. et al, 2017. Effects of traditional advertising and social messages on brand-building metrics and customer acquisition. Journal of Marketing, Vol. 81, No. 5, pp. 1-15.

Dolan, R. et al. 2019. Complaining practices on social media in tourism: A value co creation andco-destruction perspective. Tourism Management, Vol. 73, No. 8, pp. 35-45.

Dunbar, R. I. 2016. Do online social media cut through the constraints that limit the size of offline social networks? Royal Society Open Science, Vol. 3, No. 1, pp. 1-9.

Engel, B. (2001). Consumer behavior. 9 


\section{VIDEO ADS' CREATIVITY AND STRUCTURE INFLUENCE ON BRAND CONGRUENCE}

AND ENGAGEMENT

Escalas, J. E. 2007. Self-referencing and persuasion: Narrative transportation versus analytical elaboration. Journal of Consumer Research. Vol. 33, pp 421-429.

Fornell, C., \& Larcker, D. F. 1981. Evaluating Structural Equation Models with Unobservable Variables and Measurement Error. Journal of Marketing Research, 18(1), 39-50. doi: 10.2307/3151312

and Graffigna, G. 2010. The concept of engagement. International Journal of Market Research, Vol. 52, No. 6, pp. 801-826.

Gao, Y., and Koufaris, M., 2006. Perceptual antecedents of user attitude in electoniccommerce. ACM SIGMIS, Vol. 37, pp 43-50.

Gottschall, J. 2012. The storytelling animal: How stories make us human. Boston, MA: Houghton Mifflin Harcourt Publishing Company.

Graeff, T. R. 1997. Consumption situations and the effects of brand image on consumers' brand evaluations. Psychology \& Marketing, Vol. 14, No.1, pp. 49-70.

Green, M. and Clark, J., 2012. Transportation into narrative worlds: implications for entertainment media influences on tobaco use. Society for Study of Addiction, Vol. 108, pp 477-484.

Green, M. C., and Brock, T. C., 2000. The role of transportation in the persuasiveness of public narratives Journal of Personality and Social Psychology. Vol. 79, No.5, pp 701-721.

Grohmann, B. (2009). Gender dimensions of brand personality. Journal of Marketing Research, Vol. 46 , No. 1, pp. 105-119.

Hair, J., Black, W., Babin, B., \& Anderson, R. 2018. Multivariate Data Analysis: Global Edition (8th ed.) New York: Annabel Ainscow.

Hajli, N. et al, 2017. Branding co-creation with members of online brand communities. Journal of Business Research, Vol. 70, pp. 136-144.

Harrigan, P. et al, 2017. Customer engagement with tourism social media brands. Tourism Management, Vol. 59, pp. 597-609.

Hinsch, C., Felix, R., \& Rauschnabel, P. A. 2020. Nostalgia beats the wow-effect: Inspiration, awe and meaningful associations in augmented reality marketing. Journal of Retailing and Consumer Services, 53, 101987. doi: https://doi.org/10.1016/j.jretconser.2019.101987

Hennig-Thurau, T. et al. 2004. Electronic word-of-mouth via consumer-opinion platforms: What motivates consumers to articulate themselves on the internet? Journal of Interactive Marketing, Vol. 18, pp. $38-52$

Hennig-Thurau, T. et al, 2010. The impact of new media on customer relationships. Journal of Service Research, Vol. 13, pp. 311-330.

Hollebeek, L.D. et al, 2014. Consumer brand engagement in social media: conceptualization, scale development and validation. Journal of Interactive Marketing, Vol. 28, No. 2, pp. 149-165.

Klipfel, J. A. L et al. 2014. Self-Congruity: A Determinant of Brand Personality. Journal of Marketing Development \& Competitiveness, Vol.8, No.3, pp. 130-143.

Lee, J., and Hong, I. B., 2016. Predicting positive user responses to social media advertising: The roles of emotional appeal, informativeness, and creativity. International Journal of Information Management Vol. 36, No 3, pp 360-373

Li, F. et al. 2020. Social media marketing strategy: Definition, conceptualization, taxonomy, validation, and future agenda. Journal of the Academy of Marketing Science, pp. 1-20.

Mahjoub, H. et al. 2015.The Effect of Self-Congruency on Customer Behavior and Involvement International Journal of Marketing Studies, Vol. 7, No.3, pp.139-147.

Malär, L. et al, 2011. Emotional brand attachment and brand personality: The relative importance of the actual and ideal self. Journal of Marketing, Vol. 75, No. 4, pp. 35-52.

Mishra, A. S. 2019. Antecedents of consumers' engagement with brand-related content on social media. Marketing Intelligence \& Planning, Vol. 37, No. 4, pp. 386-400. 
IADIS International Journal on WWW/Internet

Mulyanegara, R. et al, 2007. The big five and brand personality: Investigating the impact of consumer personality on preferences towards particular brand personality. Journal of Brand Management Vol. 16, No. 4, pp. 234-247.

Muntinga, D.G. et al, 2011. Introducing COBRAs: exploring motivations for brand-related social media use. International Journal of Advertsiging, Vol. 30, No. 1, pp. 13-46.

Pentina, I. et al, 2018. Exploring social media engagement behaviors in the context of luxury brands. Journal of Advertising, Vol. 47, No.1, pp. 55-69.

Palmatier, R. W. et al. 2006. Factors influencing the effectiveness of relationship marketing: A meta-analysis. Journal of Marketing, Vol. 70, No. 4, pp. 136-153.

Pedersen, P. E. et al. 2003. Identity expression in the adoption of mobile services: The case of multimedia messaging services, Working Paper, 26, pp. 1-71.

Phua, J. et al. 2017. Gratifications of using Facebook, twitter, Instagram, or Snapchat to follow brands: The moderating effect of social comparison, trust, tie strength, and network homophily on brand identification, brand engagement, brand commitment, and membership intention. Telematics and Informatics, Vol. 34, No. 1, pp. 412-424.

Podsakoff, P., MacKenzie, S., Lee, J.-Y., \& Podsakoff, N. 2003. Common Method Biases in Behavioral Research:

A Critical Review of the Literature and Recommended Remedies. The Journal of applied psychology, 88, 879-903. doi: 10.1037/0021-9010.88.5.879

Schivinski, B., and Dabrowski, D., 2015. The impact of brand communication on brand equity through Facebook. Journal of Research in Interactive Marketing, Vol.9, No.1, pp. 31-53.

Schivinski, B., Christodoulides, G., \& Dabrowski, D. 2016. Measuring Consumers Engagement With Brand-Related Social-Media Content. Journal of Advertising Research, 56(1), 64. doi: 10.2501/JAR 2016-004

Sirgy, J. M. 1982. Self-concept in consumer behaviour: A critical review. Journal of Consumer Research, Vol. 9, pp. 287-300.

Sirgy, J. M., and Su, C.2000. Destination image, self-congruity and travel behaviour: Toward an integrative model. Journal of Travel Research, Vol. 38, No.4, pp. 224-235.

Tsai, W.-H. S. and Men, L.R. 2013. Motivations and antecedents of consumer engagement with brand pages on social networking sites. Journal of Research in Interactive Advertising, Vol. 13, No. 2, pp. 76-87.

Torelli, C. J. et al, 2012. Brand concepts as representations of human values: Do cultural congruity and compatibility between values matter? Journal of Marketing, Vol. 76, No. 4, pp. 92-108.

Utz, S. et al. 2015. Snapchat elicits more jealousy than Facebook: A comparison of snapchat and Facebook use. Cyberpsychology, Behavior, and Social Networking, Vol. 18, No. 3, pp. 141-146.

van Laer, T., de Ruyter, K., Visconti, L. M., \& Wetzels, M., 2014. The extended transportation-imagery model:

A meta-analysis of the antecedents and consequences of consumers' narrative transportation. Journal of Consumer Research. Vol. 40, No 5, pp. 797-817.

Verduyn, P. et al. 2017. Do social network sites enhance or undermine subjective well-being? A critical review. Social Issues and Policy Review, Vol. 11, pp. 274-302.

Westberg, K. et al, 2018. An examination of how alcohol brands use sport to engage customers on social media. Drug and Alcohol Review, Vol. 37, No. 1, pp. 28-35.

White, K. and Dahl D.W. 2007. Are all out-groups created equal? Consumer identity and dissociative influence. Journal of Consumer Research, Vol. 34, No.4, pp. 525-536. 